\title{
The Process of Internationalization of JAC Motors in Brazil From the Standpoint of Sustainable Organizational Behavior
}

\author{
Renata Martins Corrêa ${ }^{1}$, Suzana Bandeira ${ }^{2}$, Flavia Frate ${ }^{3}$, \\ Claudio Bezerra da Silva ${ }^{4}$, Gilmara Lima de Elua Roble ${ }^{1}$ \\ ${ }^{1} \mathrm{FEI}$, São Paulo, Brazil; ${ }^{2} \mathrm{FECAP}$, São Paulo, Brazil; \\ ${ }^{3}$ FATEC, São Paulo, Brazil; ${ }^{4}$ FMU , São Paulo, Brazil \\ E-mail: renatacorreaprof@gmail.com,suzana@ \\ bgcorporativa-cultural.com.br, claubezerra@gmail.com, \\ flaviafra@hotmail.com, gilmararoble@gmail.com
}

\begin{abstract}
The present study has the target of understanding the process of internationalization of the Chinese automaker JAC Motors in Brazil, as well as identifying if the Brazilian group SHC that brought it to the country and controls its operations in the Brazilian market holds a sustainable organizational behavior. The theoretical basis used to understand the internationalization process was the economic theories described by Dunning and behavioral theories from Uppsala University. In addition, we looked at documents and data from the Chinese government in order to understand the policy towards sustainability and innovation processes in the country. Also a vast bibliographic research has been performed regarding the term sustainable organizational behavior in order to support the research made over the SHC group in which we approached the questions related to the interest the group had on JAC Motors, which drove JAC Motors to get into the Brazilian market, questions regarding sustainable management, resources allocation as well as aspects related to innovation and technology.
\end{abstract}

Keywords: Internationalization, China, Sustainable Organizational Behavior 


\section{INTERNATIONALIZATION}

Internationalization is a concept remounting ever since the beginning of man's history and civilizations. Man has somehow developed several different ways of doing business over the borders. "The entry into international markets involves uncertainties, risks and complexity. Uncertainty results into the need of operating in very distinguished markets than the domestic market, that is, in environments in which the political, social and economic systems along with legal standards may be completely different" (TANURE, 2006, p.07).

Aiming at the enhancing of a strategy for international expansion, companies are searching foreign markets for several reasons, such as, economy of scales studies, need of growth, search of efficient processes and natural resources, manpower availability, access to capital at a lower cost, use of already developed existing technology, specialized knowledge via acquisitions, favorable government measures for tax incentives as well as risk reduction as the geographical variation reduces company dependency on a single market (PORTER, 1986; DUNNING, 2001; YIP, 1989, 1996).

From Porter's perspective (1986, p.260), "one industry becomes global basically because there are economic advantages for a company to compete in a coordinated manner inside several national markets".

Several theories present distinct approaches for the entrance of foreign companies into the domestic market, however this study intends to approach two main currents, one understood as Economic Theory which main representative is Dunning $(1980,2001)$ and the other current is the School of Uppsala directing to Behavioral Theory.

According to Dunning (1980), the theory of internationalization with the approach of economic environment explains the decision of manufacturing or not in an external foreign market by means of economic drive where structure and cyclic variables are conditioned, such as, the country's and the industry's characteristics with operation variables and company's specific strategies.

As Dunning (1980) understands companies should prepare to compete with other companies already positioned in foreign markets. They should achieve advantages to make up the costs of operating in new environments. Thus, the author directs three elements: ownership, location and internalization (OLI).

For Dunning (1980) the first element (ownership) is about the advantages related to location. These are intangible assets that involve resources developed by the organization which are not available for competitors, and allow a better position in the international market. Among these we can highlight knowledge and technical abilities, the opportunity of investment depending on size of the local market, product diversity and higher productivity.

The second element, (location); this is related to the host market receiving the investments. Likely this includes intangible assets resulting from implied knowledge, the existence of location advantages are also favorable to local production rather than exportation and licensing. A company locates their activities to gain access to manpower, capital, material and other cheap raw materials, or to have sales closer to their customers and avoid transportation costs and tariffs. These are attractive alternatives in countries and regions that offer advantages and structures to create resources and capabilities. 
At last the author provides evidence of internalization where a company analyzes the economic advantages between exportation and local production, if the costs of incorporation and productive organization are lower than the transaction costs associated with the transfer of such capabilities to a local manufacturer, the company will transfer the assets for manufacturing in this market. "When the company internalizes it, this company decides to manufacture to obtain either economy of scale or reduction of the costs of transactions and coordination resulting from uncertainty, and the existence of externalities" (DUNNING, 1980, apud BELMIRO et. al 2008, 2012).

The second current classified as Uppsala University translates actions oriented by behaviors from the business environment of the company also known as Behavior Theory. (JOHANSON; WIEDERSHEIM, 1975; JOHANSON; VAHLNE, 1977, 1990; BILKEY, 1978).

Johanson e Vahlne (1977) yet observed that the choice of target countries follows a certain logic of proximity in aspects such as geography, culture, economy, known as psychic distance, that is, the bigger the difference between the country of origin and the foreign country in terms of development, educational level and content, language, culture, political system, among others the higher the level of uncertainty.

For Carlson (1951), the process of internationalization according to Uppsala University, by analogy it is similar to walk with caution over an unknown site. Unknown conditions of local businesses, customer profiles and their respective acceptance, bureaucratic proceedings, the government changes, distance from the headquarters, all these generate uncertainties for the whole allocation of all kinds of resources.

Therefore, according to this school, companies should have caution in their development within other markets, applying gradual penetration aiming at knowledge and experience within the local environment. Thus, companies increase the trust for the investment of resources in the country and slowly build the process of internationalization as the learning over the local market grows and provides the foundations for the company's strategic decisions in the foreign market. So on a first moment the company decides to start their activities through exportation what should be at a relatively lower cost of operations and lower risk exposure. (JOHANSON;VAHLNE,1977).

Concurrently, Cavusgil (2011) states that as the company reduces uncertainty over experience and knowledge acquired in the activity they can allocate more resources and progress with internationalization.

In the same line of thinking, authors such as Johanson and Mattsson (1990) finalized the thoughts of the Uppsala University as they informed that as the company increases their knowledge over economic, social and cultural aspects about the competitors among other factors, the organization starts to set and establish their own subsidiary.

Other forms of internationalization are the application of speculative capital in stock market and foreign direct investment which capital is focused on manufacturing and long term results. Internationalization may yet be characterized by the transfer of know-how in exchange of financial advantages, and market policies and strategies.

According to Salvatore (1999 p.25), "international economy deals with economic interdependency between nations. It analyzes the flow of assets, services and payments between 
one nation and the rest of the world, the policies directed to the regulation of such flow and its effects over the welfare of a nation". In general, when a company decides for its process of internationalization, the objective is expansion of its products and services into different markets and regions of the globe. According to Cavusgil $(2011$, p.78) "Companies also pro-actively search internationalization due to several internal forces such as search for growth and customers or yet to minimize the dependency on the domestic market by means of geographical diversification".

We will approach then some policies to support internationalization directed by the Chinese government in order to understand the way the process is operated.

\section{ABOUT CHINA}

From the beginning of the Reform made by Deng Xiaoping in 1978, China has taken advantage of certain conditions, such as, available manpower, cheap and eager to improve their lives and work conditions; they also take advantage of how attractive their growing domestic market is for international companies and thus they make their economy as flexible as possible generating exchanges and learning. Kissinger (2011) states that in a time of economic crisis, China has played an unprecedented role: "in the past the Western world usually applied to China several foreign restrictions forecasted in their economic policies, now the country is more and more an independent proponent of its own solutions and a source of emergency help for other economies facing the crisis." ( KISSINGER, 2011 p.461).

China has already been the center of world for innovation. Weapons, compass, paper, gun powder and printing were invented over a thousand years ago. Scientist and historian Joseph Needham - whose work Science and Civilization in China has set ever since 1950 this subject in details (WINCHESTER, 2008). According to a document from the U.S.Chamber of Commerce, written by McGregor (2009), it is believed that China lost "their hand" over innovation due to a "bureaucratic feudalism". The Western world took advantage of these innovations, improved them and used them as a base for centuries of technological domination ${ }^{1}$. Having a model under construction, China produces almost everything under several modalities and association arrangements. It became in 2010 the largest world exporter as well as the second largest world importer only behind the US. A significant part of its importation corresponds to products and components of high added value besides raw materials and commodities. In the last 10 years the country leaders have pointed out innovation as a means of repositioning China in the world and sustaining its development keeping in sight the price this growth has charged the nation: inequality, pollution, poverty in rural areas and environmental degradation ${ }^{2}$.

\section{RECOVERTING THE ROLE OF SCIENCE AND TECHNOLOGY AND THE NATIVE INNOVATION}

When Deng Xiaoping lauched the Reform and Opening of the country in 1978, he immediately put his efforts to science and technology as keys to modernize China. Along the 80 's and early 90's, science, the reforms of the system of technology and new programs rapidly progressed. This progress of science and technology was top of mind raked by President $\mathrm{Hu}$ 1 The Economist 25 Year Special Edition - The World in 2011 - Going for a Song ? Geoffrey Carr. http://www.economist.com/theworldin/2011

2 The International Finance Corporation (IFC), filiado ao Banco Mundial, China's Emerging Private Enterprises Prospects for the New Century, 2000. 
Jintao and prime minister Wen Jiabao when they started their ruling in March 2003. In October 2005, the Central Committee of PCC raised native innovation to a strategic level as that of the policy of "reform and opening of the country" from Deng Xiaoping. Hu Jintao said that China would follow a new path of innovation: "innovation with Chinese characteristics ". Native innovation campaign achieved the level of national strategy that would place science and the technology development in the center of the re-balance for China in terms of industrial structure and development standard (McGREGOR, 2009). Along with this guideline we are able to notice the existing industrial policies directed to production expansion and sustainability of payment balance. These two elements control the pace and the direction of the Chinese IDE and set the degree of intervention from the State (ACIOLY e LEÃO 2011).

\section{FROM VOLUME LEADER TO LEADER IN INNOVATION AND SUSTAINABILITY}

With a strategy focused on development of new technologies, the Chinese automotive industry intends to join quality, safety and mainly environmental issues thus paying less attention to manufacturing records ${ }^{3}$. According to data from International Organization of Motor Vehicle Manufacturers (OICA) in 2011 China manufactured 18,4 million vehicles and holds the position as the largest world manufacturer. In April 2011, the Forum of OICA held in Shanghai in partnership with the Chinese Association of Automobile Manufacturer (CAAM), discussed topics about energy economy, environmental protection, low carbon emission among other important challenges to be faced by the automobile industry. Chinese authorities present at the event informed that the next five years will be a landmark for the transition of the development of electric vehicle industry. Mr Su Bo, vice-minister for Industry and Information Technology Department highlighted:

The 12th five-year plan for the automotive industry forecasts a strong development both technical and scientific over the need of opening of the Chinese automotive industry promoting independent development and innovation. The development of independent brands needs to be accelerated. The whole system, from product to organization structure should be focused on saving energy, new energy and sustainable development setting up a consolidated base for the automotive segment in the Chinese industry ${ }^{4}$.

\section{THE INTERNATIONALIZATION OF CHINA IN THE WORLD}

Since the end of 90's the Chinese government has adopted an internationalization strategy for their companies as a basic tool for economic development and for the country's geopolitical insertion. "To do so, in the XVI Congress of the Communist Party in 1999 the program Going Global was prepared aiming at the following four major objectives:..." i) increase Chinese investments abroad by means of decentralization and relaxing the authorization concessions allowing Chinese industries to leave; ii) improve of the level and quality of projects; iii) reduce capital control and create new channels of financing for the domestic market; and iv) integrate the internationalization policy for Chinese companies with other existing policies for the foreign

3 Report published in the Brazilian newspaper BrasilEconomico on Oct 142011 http://www.brasileconomico.com.br/noticias/china-busca-lideranca-no-setor-de-carros-sustentaveis_108082.htm

।

4 Constructing the Global High-end Exchange Platform and Leading the Sustainable Development

for Global Automotive Industry "2011 OICA China Forum" in Shanghai 
segment searching to promote brand recognition of such companies (ACIOLY and LEÃO 2011; HOLLAND and BARBI, 2010).

In accordance with the study made by the Applied Economy Institute (IPEA) in 2011, the flows of Chinese direct investment in the world have multiplied by 60 times between 1990 and 2008, according to United Nations Conference of Trade and Development (Unctad). When China started its opening process, these investments moved from a figure close to zero to reach US\$ 830 million in 1990 and later US\$ 52,1 billion in 2008. The acceleration of this growth was higher from 2004 when a series of changes in the policy of incentives to internationalization was implemented. From this point on, Chinese investments were made to supersede the investments made abroad from other Asian countries, such as, Korea and Singapore, and then in 2008 China became the second largest investor among developing countries just after Hong Kong.

The internationalization process of Chinese companies by means of foreign direct investment (IDE) is sponsored and managed by the Government (GUGLER and FETSCHERIN, 2010). Made through loans and administrative proceedings among other incentives (ACIOLY and LEÃO, 2011).

The Government encouraged companies by means of financial devices and ease of administrative processes to perform IDE. For Holland and Barbi (2010), this expansion of the Chinese IDE is a result of the governmental strategy that articulates on one side the control over energy and food vendors, and on the other side, the expansion on sectors where the Chinese industrial companies have been developing (automobile, computer systems and telecommunications etc.), even when there is a vast domestic market to be exploited. The Government's capital is represented by a province or city. These are companies with more managerial independence having part of their ownership structure negotiated in the stock market. Among these we can mention as examples, JAC Motors, Chery, Xuzhou Construction Machinery Group and Chongqing Grain Group ${ }^{5}$.

\section{THE INTERNATIONALIZATION OF CHINA IN BRAZIL}

The most usual entrance manner used to announce and bring Chinese foreign direct investments in Brazil has been through partly made Mergers and Acquisitions ${ }^{6}$. The study from the Brazil-China Entrepreneurship Council (CEBC) explains that one of the reasons for such preference is based on the difficulties regarding cultural differences. According to the data from the Applied Research Institute (IPEA) in April 2011, the main sector destination of Chinese FDI in Brazil in 2008 were: retailer business of pesticides, fertilizers and soil correction (37\%); manufacturing of semi-finished steel $(14,1 \%)$; and manufacturing of malt, beer and draft beer $(13,7 \%)$.

In 2009 it was observed a change in the sector participation of the Chinese Foreign Direct Investment as those that represented the largest participation were the following: multiple banks with commercial customers (73,2\%); retail businesses of pesticides, fertilizers and soil correction (4\%); and combined services for office and administrative support (4\%). Considering that Chinese state industries also sent resources from their base to foreign countries, the flow

$5 \quad$ Study published by the Brazil-China Entrepreneurship Council in March 2011 
data for Chinese FDI are distorted and underestimated ${ }^{7}$. In the segment of automakers we highlight the entrance of the following Chinese companies: Chery, JAC Motors, Dongfeng and Sinotruck. These are products manufactured from European designs and international system technician analyst as well as a strong dealer's network and after-sales ${ }^{8}$.

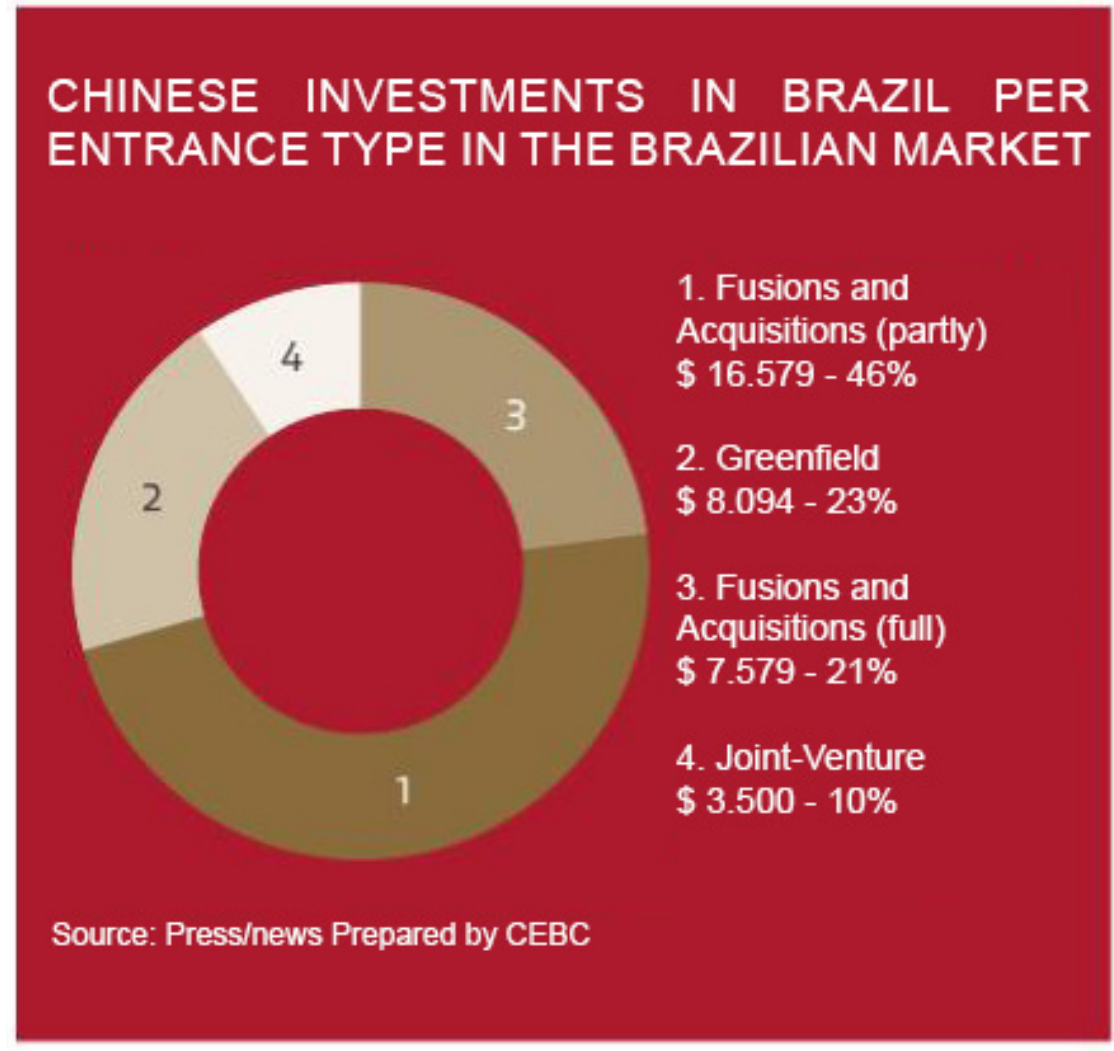

Figure $\quad 1-\quad$ Chinese Investments in Brazil by entrance means

Source: News press - CEBC / March 2011 (adapted)

In accordance with the study made by the CEBC, these automakers compete with challenging characteristics, such as, advanced technological resources, proper luxury models, competitive prices regarding the Brazilian industry in equivalent category. Chery and JAC are Chinese Government companies that invest in the Brazilian market. The first one already has 73 authorized dealers and a project announced to install a plant in the country. The latter one which is also targeted at our study, JAC Motors has a large dealers' network with 50 units. They adopted the strategy of early internationalization as they have the freedom to sell their cars in other markets. Chery and JAC have existed over 10 years with products found in over 100 countries.

Understanding the Chinese policy regarding global strategies addressing internationalization processes, innovation and sustainability in the world and in Brazil is key, the following will describe the main concepts of sustainable organization behavior by means of theoretical references in order to help us understand how it actually took place in Brazil with the Chinese company JAC Motors.

$7 \quad$ IPEA studies \# 85 April 2011 


\section{SUSTAINABLE ORGANIZATION BEHAVIOR}

According to Derek Pugh (1971 apud Caravantes 2009, p. 27), organizational behavior is "the study of the structure, functioning and performance of the organizations as well as the behavior of groups and individuals part of such organizations".

Organizational Behavior according to Caravantes (2009), is to be concerned with the performance of workers in the organization environment; the effect of formal and informal groups; feelings and actions of workers; the effect of workers over the organization regarding efficiency, efficacy and effectiveness. Yet according to Hobbins (2010, p. 07).

Organizational Behavior is a field of studies that investigates the impact individuals, groups and the structure have over the behavior of people within the organizations with the intent of using this knowledge to improve organizational effectiveness.

Currently, the need of changes in the organizational strategies is inherent to its survival in the globalized market.

For an organization effectively follow these changes and remain solid, one of the strategies to be concerned about is the understanding of this external scenario and implement a system to learn the concepts of sustainable organizational behavior.

It is notorious that the concept of sustainability is today a significant part of the ideas of most communities around the world, how to preserve biodiversity and natural ecosystems, respect the environment and demand from companies social environmental quality in products and services to be offered to consumers. It is within this perspective that Kofi Annan awarded Nobel Prize for Peace stated "Sustainable development is essential for everlasting peace. Above all it is the reason to be for the United Nations".

So in 1987 the United Nations' World Commission for Environment and Development prepared a report called "Our Common Future" also known as "Brundtland Report" which defined sustainable development as "the one capable of supplying the needs of the present generation without compromising the supplying of needs and survival of future generations" (BRUNDTLAND, 1987, p.27).

Trying to make this concept more tangible, John Elkington (1994) created the concept called Triple Bottom Line, or tripod of sustainability where he states that sustainability from a business point of view should be based on three dimensions in balanced and interdependent manner as follows: economy, social/human and environment what is demonstrated in Figure 2 . 


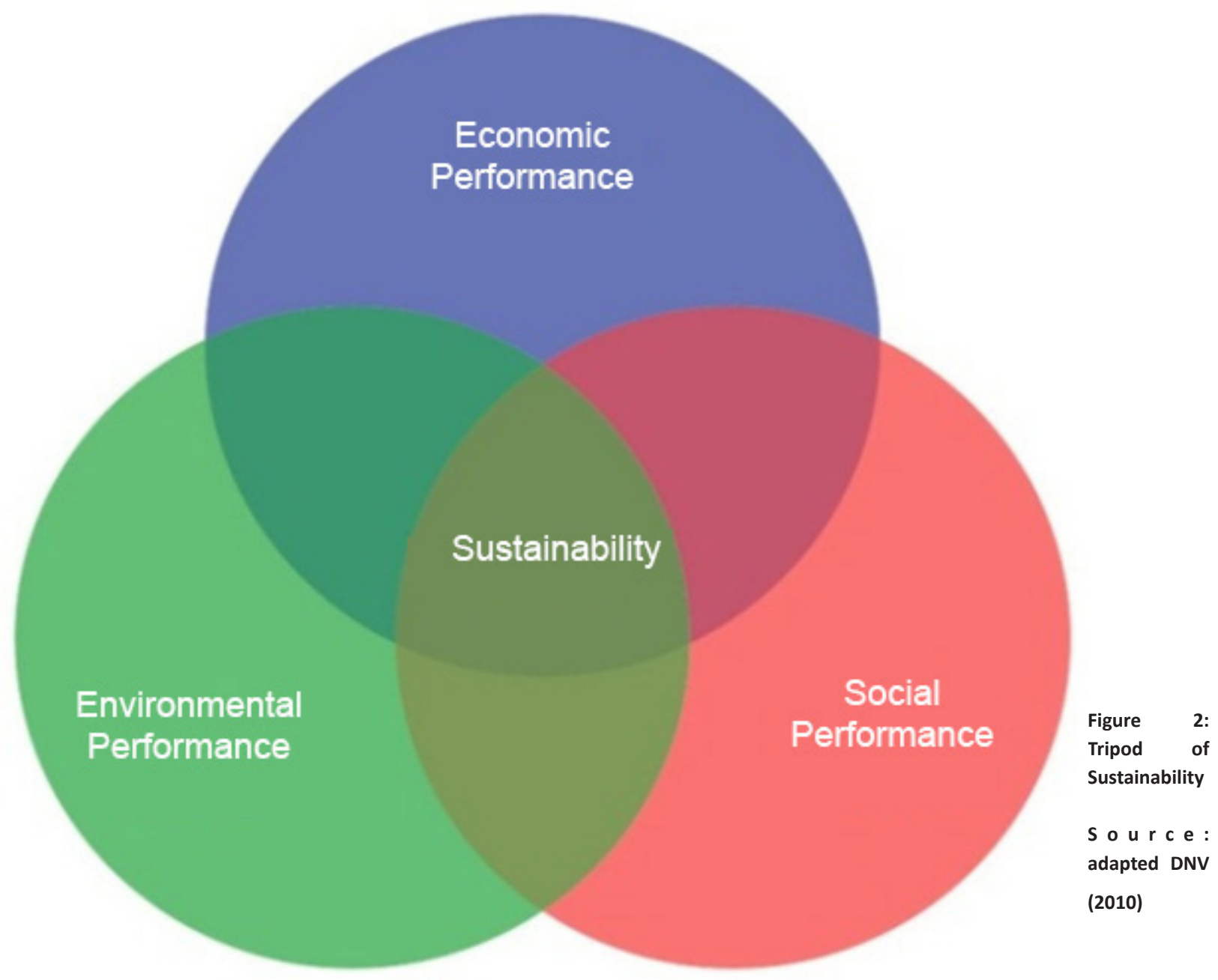

From the same perspective, the Guide for Communication and Sustainability prepared by the Brazilian Business Council for Sustainable Development (CEBDS) in 2008, lists the actions related to the tripod of organizational sustainability as detailed below:

In the economic dimension it is understood that the offer of goods and services at accessible prices at an increasing number of consumers; development of infrastructure for the construction of new inclusive markets and actions to influence and spread good practices for several segments; the incentive to activities for income generation, micro-credit and fight against poverty in the value chain; the expression in sustainability strategies adding value to the relationship with investors (CEBDS 2008).

In the social dimension the development of tools designed to follow up quality and safety of products and services as well as the satisfaction and right to data disclosure for consumers; the development and adherence to laws, regulatory standards and volunteer codes concerning marketing, institutional communication, promotion and sponsorship; the utilization of tools for communication to encourage consumers in 
a sustainable manner (reduce, reutilize and recycle); respect to international labor conventions and human rights, slave work and infant work; respect labor legislation and the right to free association of workers; respect to social, cultural and religious differences and value of ethnic and gender diversity within the company and in their relationship with stakeholders, that is the public that relates to the company; the development of programs for salary leveling between man and woman, policies, procedures and training of employees and associates in fighting corruption, strategies and programs to improve health conditions for workers and community; creation of strategies and programs to improve the education of workers and the development of qualified manpower, among others (CEBDS 2008).

In the environmental dimension the development of tools for the manufacturing of goods and services allied to a capacity to preserve ecosystems and environmental services.: air, forests, soils, water, energy and food; ecoefficiency in manufacturing processes: produce more generating less environmental impact and consuming less natural and financial resources; optimize the use of raw material, sources of energy and water from re-use and recycling; reduction of waste of raw materials, water and energy; the correct disposal of effluents from manufacturing processes; the capacity to know and reduce the level of gas emission which cause the greenhouse effect in manufacturing processes; the reduction of the impact from the transportation of goods, products and materials used in manufacturing processes and in the transfer of employees; the development of programs for preservation and reduction of the impact over biodiversity; investment in innovation and clean technology for the development of goods and services of quality and high performance; the development of spare logistic processes for the disposal and recycling of products at the end of its cycle of use (CEBDS 2008).

Therefore, we can understand that a company when it starts working with sustainability has as premise of a harmonic relationship between economic agents, community and nature. This implies in a political, social, cultural and ethical revolution, Briefly we can define it as a model that allows economic growth without social exclusion and respects the environment. Its spread will depend on all the actors from the community, the Government, citizens and entrepreneurs to understand that sustainable management is a matter of survival for companies and forthcoming generations.

Ashley (2003) reminds that for some social responsibility represents legal obligation; for others it means a responsible behavior in terms of ethics; for others yet, the message transmitted is to be responsible, and many believe it is charity; and some others take it by the sense of social awareness. Corporate social responsibility is the set of social actions taken by the company aiming at promoting welfare either internally or externally which is seen from broader view as organizational sustainability.

Ethos Institute of Social Responsibility highlights the importance of a way of leading business in which the company becomes a partner and co-responsible for social development. A socially responsible company is the one that has the capability of listening to interests from different parties, such as, shareholders, employees, vendors, suppliers, consumers, community, government, environment, and yet try to incorporate all of them in the planning of its activities, 
searching to address demands from all of them and not only from shareholders or owners.

Corporate social responsibility may be interpreted and practiced as an ethical compromise from the organization in its actions and relationships with the several publics with which it relates. Thus, the concept goes beyond the legal posture from the company, philanthropy or support to the community, social corporate responsibility is an attitude from an organizational management with the proper value to everyone.

Thus, organizations need to reinvent their businesses and remain profitable, however financially healthy, but also they have to be managed through values and fully in accordance with the system in which it is inserted. "In a world that the natural capital, social capital and human capital are subject to restrictions, considering just a return over financial capital holds back companies into the shadows of a distant past." (SENGE, 2009 p.345). The same author states that today modern companies conceived and managed as "money making machines" are not in harmony anymore.

For Senge (2009) some traditional businesses considered sales to be more important than actually adding value to customers. Side effects of this approach are dissatisfied customers and overflowing landfills, this happens because of the disconnection between organizations and their customers.

In the same line of thinking, author Barrett (2009) informs that we are getting to the era of compassionate capitalism. When selling their products and services, companies need to have basis on values and rules that support common welfare. Ethics and social responsibility are fundamental for the way companies conduct and communicate their businesses. Values that define how companies stand in the community are more and more important on the consumer's decision making and on retaining talents at a company.

"We may carry on spending more time satisfying our selfish needs and greedy egos or maybe we can choose to create a future where we will feel good within, raising our souls and at the same time make it more sustainable for all of us, for the businesses and for the community" (BARRET, 2009, p.24).

For Barrett (2009) companies are yet waking up for this new paradigm. There is still the "cannibalism" being encouraged through numerous limiting values by some companies. Fierce competition, a badge is used as a symbol of power, people are stressed out and afraid of the work environment because they are not able to meet their targets, other people working twelve or fourteen hours per day without any free time to address the needs of other sides of their own lives.

Author Barrett (2009) supports that companies which still feed this kind of culture are short term focused with outdated management and leadership practices. It is necessary to balance this polarity to become an everlasting company with associates who are fully satisfied with their jobs. The change of paradigm is about balance, that is, balance of the organizational and human needs.

Senge (2009) alleges that organizations are recognizing the need of change, either because they need to survive or because they are searching benefits in order to operate in a more sustainable manner, for instance, cost reduction or a better company image. They see the connection between their own survival, advantages of opportunities of advance and preservation of the environment. Companies that are in this stage are going over the line between merely 
reacting to risks on one side and recognizing the opportunities from active creation of a world in which they will be able to be prosperous indefinitely, on the other side.

It is known that organizations need control to keep the order, however, the argument of the authors is that organization cannot focus business strategy exclusively on this view, but on corporate governance that is open and flexible.

Barrett (2009) describes this level of organizational awareness as adaptability, sharing power of the employee and ongoing learning. The author understands that to encourage innovation so that new products and services are developed, it is necessary that the enterprise goes through changes and incorporates values of flexibility and takes risks during management. In addition we have organizational culture migrating from control to trust, from punishment to incentive, from exploitation to property, and from fear to truth. And thus, mechanisms are set up to promote innovation and learning. The focus simply on financial result starts to disappear as the organizations start to measure its success in comparison to a wide range of indicators. Vision, mission and values are recognized as means to develop a strong organizational identity.

The company is considered a "citizen" when sustainability is fully integrated to the strategy, in general it happens when companies discover that they have a much wider range of business opportunities, but only if they pro-actively incorporate the factors of sustainability in all dimensions of their business strategy and in the core of their processes of investment and decision making, in all organizational levels. (SENGE 2009, p.115).

Senge (2007) indicates that more and more businesses are incorporating sustainability issues among their objectives for the future. For Senge true innovation demands a distinguished mentality.

Concurrently with Senge, Barrett (2009) says that the primary focus of organizations in this level of awareness is the service to humanity and to the planet. There is recognition of the inter-relationship of life as a whole and the need of individuals and organizations to take up the responsibility for the entire welfare. Internally, the focus of the organization is to create an ethical environment including justice, humility and compassion. Externally, the focus is to understand the impact of present actions in the forthcoming generations, that is, to create a sustainable future for the company and the community.

According to Kuazaqui (2010) companies have been noticing that they can differentiate from their competitors using practices overlooking optimization of non-renewable resources. During many years there has been a concern of contributing financially with programs related to the environment. Currently the practice is to spread the utilization of new technologies and the offer of products and services that are politically correct. Then companies get positive exposure before different groups of interest and at the same time reducing costs, expenses and processes.

Thus, the International Organization for Standardization (ISO), holds together over a hundred countries and regulates by means of ISO 14000, standards that aim at reducing the load of pollution generated by companies in the manufacturing system as well as the wastes of raw materials. In Brazil, the whole process of certification is managed by the Brazilian Association of Technical Standards (ABNT). Companies that meet the standards receive a certification that is worldwide valid. Therefore, in addition to competitive differential, companies may obtain gains by means of economy of scale and productivity reached in the processes of manufacturing. 
Brazilian industries have searched cleaner technological alternative and less toxic raw materials in order to reduce the environmental impact and degradation. The community's awareness and the environmental legislation have led companies to a more sustainable relationship with the environment. Companies have been forced to invest in process modifications, manpower improvement, raw material replacement, reduction of residue generation and rationalization of the consumption of natural resources.

In this context for Sachs (2004) the sustainable dimension of development drives us to "[...] search solutions that are triple winners eliminating the wild growth obtained at the cost of highly negative externalities both social and environmental" (SACHS, 2004, p.15).

Sen (2011) completes the theory mentioned by the authors when he observes that in spite of many human activities that follow the process of development may have destructive consequences, yet it is also at reach of human power to enrich or even improve the human environment.

Therefore, the civilian community, companies and the government and all those in charge of the maintenance of the planet we live in.

The following example is of sustainable manufacturing process in an automaker that has been present in the country for the past 87 years.

\section{AN EXAMPLE IN BRAZIL}

GM Brazil is an American company that manufactures cars focusing on processes that are sustainably managed, besides investing over $\mathrm{R} \$ 5$ billion in the country, and holding almost 600 points of sales and services and the largest line of dual fuel vehicles (gasoline and ethanol) in the market, GM demonstrates that is necessary to manufacture cars focusing on sustainability.

According to Franco (2010) the company has one of the most modern buildings for their technological center constructed in accordance with the concept of "Green Building", that focus on reducing the utilization of electrical energy and natural resources and the areas of stamping and painting where sustainable practices are also placed at a first level. They value suppliers as business partners and an important part of the compromise of corporate responsibility. The company presents a "zero tolerance" policy against infant work, improper treatment to employees or the practice of corrupted business for the supply of goods and services. In addition to that, they present the guidelines ruling a responsible business conduct including treatment of workers and the role of the company enhancing local communities in which they work.

One of the environmental principles of GM is to reduce the generation of waste. All their units practice composting in which organic residues are transformed into fertilizer for trees and green areas. The company has already designed approximately 1.400 tons of residues to composting. Other sustainable actions are the recycling by means of process of selective collecting of cardboard, paper, plastic, wood, batteries, lamps, metals among others where they recycle $97.7 \%$ of what is utilized. In addition, they treat effluents what consists of treating water used in their manufacturing processes and return it to nature. The company is pioneer in the automotive segment as they implemented this type of station in 1951 at their plant in the city of São Caetano do Sul. Other essential issue is the re-use of water which not only creates alternatives to reduce the consumption of potable water. The company re-uses rain water for what it has adopted an automated re-utilization system that collects water by means of pipes and drains and directs it 
to a reservoir where the water is treated with chloride for later use in lavatories and flush toilet. The company is also aware of an optimized use of water in their manufacturing processes. This is applied in painting, for instance, one of the areas with the largest use of this natural resource. In the stages of pre-treatment, the body of the car passes through several baths in which it is made ready for painting. The area has worked on the re-use of water in more than one stage of washing in order to reduce consumption. Other initiative present in the painting of cars is the use of paints with higher solid content, and thus, the paint has better yield, less smear and a more concentrated paint takes less solvent in its formula resulting into less emissions of volatile organic compounds in the drying hoods.

All GM do Brasil units have an incineration system in charge of reducing $99 \%$ of its emission. GM also adopts the practice of turning off all machines during non-productive time as well as eliminating every type of leakage. The outcome of such measures: from 2004 to 2008, GM do Brasil reduced in 35\% the consumption of water and electrical energy in their business units. From 2003 to 2009 there was a drop of 51\% over electrical energy consumption per vehicle manufactured, and $62 \%$ over water. Nanotechnology causes a reduction of $90 \%$ on the generation of phosphate burr and saves the consumption of 26.000 .000 liters of water /year. In the technological center in the city of São Caetano do Sul, a more efficient air conditioning reduces $13 \%$ the consumption of energy. With the use of glass cups, 1.320 .000 plastic cups/ year were eliminated. With the elimination of plastic bags to wrap silverware, 624.000 plastic bags /year were eliminated. GM do Brasil also invests in social projects as part of the company's strategy supporting educational programs and qualification of manpower; their priority are the cities where their business units are located. Their associates are offered incentive programs along with a private sports club where they are allowed to take their families as well as several other benefits.

Today GM Brasil is the second largest operation of General Motors outside the US and consolidated as one of the five global development centers of vehicles in the company. This is because they are able to perform all stages of creating a vehicle, from design to validation and to trading in a sustainable manner on all their processes, and yet they export technology to GM around the world.

Below we are going to approach the methodology used in the present study.

\section{METHODOLOGICAL PROCEDURES}

First a vast bibliographical study was performed with the objective of reviewing the data referring to the concepts that approach internationalization of companies, the policy of the Chinese government and the sustainable organizational behavior. We searched several sources of evidence such as: secondary data research, document analyses and interviews performed by means of a semi-structured questionnaire.

The Chinese company JAC Motors was chosen as the business unit object of this research due to the process of internationalization in Brazil in a non-conventional manner as the initiative came from a Brazilian group that holds approximately $90 \%$ of shares in Brazil.

Thus, the methodology used to collect such information was the case study by means of open interviews for more details with a public relation worker from group SHC that represents JAC Motors in Brazil. The interview performed in July 2012 was preceded by the development 
of a protocol of case study (YIN, 2005). In order to understand the company's organizational structure and the internationalization process were approached issues related to the interest of SHC group by the company JAC Motors as well as what drove the Chinese company JAC to get into the Brazilian market and the impacts of the organization and yet understand if the group intended to work with sustainable management in all of their processes and issues related to the allocation of resources, innovation and technology.

\section{THE ENTRANCE OF THE COMPANY JAC MOTORS IN BRASIL}

Jianghuai Automobile Co., Ltd. - later denominated JAC Motors - was founded in 1969 and is present in more than a hundred countries. In the beginning the manufacturing was exclusively for trucks, but overtime, the factory grew and modernized. Today, they have a diversified line of vehicles that meet the needs of several segments in the automobile market.

The process of internationalization of JAC Motors in Brazil started in 2010 where the SHC group, led by Sergio Habib, announced a partnership with the company to represent the Chinese brand in Brazil.

The process of internationalization was not conventional because it was an initiative from the Brazilian group SHC, the initiative was to bring to the country this Chinese automobile brand. We are talking of a project that was over BRL\$ 1 billion. As any other project, there are challenges. The SHC group the controller of the Chinese brand has acted over twenty years in the importation and distribution of the brand Citroen. After re-organizing the structure of the brand, Sérgio Habib decided to prospect in different parts of the world for new brands of automobile. Thus, the SHC group analyzed four factors that determine the choice for JAC Motors as a partner to act together in the Brazilian market. The first was to notice that the company is in constant growth investing in new manufacturing processes focusing on the constant improvement of quality. Secondly, as they had a center of design in partnership with the studio Pininfarina in Turim, Italy; and a center of development of interior design in Tokio, Japan. And third, because JAC vehicles have both external and internal design that match the taste of Brazilian consumers, and most importantly, they have an excellent portfolio of vehicles development. And finally, the fact that JAC, according to the surveys made is one of the Chinese brands with excellent rates of quality.

JAC Motors brought to Brazil cars that have high performance engine and European technology. The engines are more resistant and offer more acceleration and a significant saving on fuel.

The process of internationalization of JAC Motors in Brazil takes place in two stages. In the first stage, the SHC group invested BRL\$ 350 million for the importation and distribution of vehicles. This process triggered the immediate opening of fifty authorized dealers, in addition to a modern center of part distribution which demanded investments of BRL\$200 million. For the launching of the brand and the start of operations we allocated BRL\$120 million.

The second stage will be the implementation of a plant in the city of Camaçari in the state of Bahia, forecasted for 2014. This project will demand investments of BRL\$900 million out of which BRL\$ 780 million are from the SHC group and BRL\$120 million from the headquarters of the group JAC Motors out which $87 \%$ of domestic capital from the SHC group therefore having Brazilian control and management which will result into more jobs and income for the local 
community besides helping the economy. We should highlight that part of the financial drive of the SHC group will be made by investment agents, such as, the Brazilian Bank of Economic and Social Development (BNDES).

The choice of the city of Camaçari is because of three structural items: a) suppliers already installed and the culture of manpower spread in the region; b) logistics advantages: roads and harbors with the perspective of growth; c) proximity to points of consumers, for instance, the Brazilian Northeast region that has been showing a strong potential of economic growth.

The plant in Brazil will rely on a center of development for new technologies; center of style and design; control labs for pollutants emission; test track and center of professional development.

Currently, the SHC group has 89 authorized dealers in Brazil out of which 50 are from JAC, this figures should grow to 200 in 2014 with the implementation of the plant and the other brands.

Therefore we understand that the creation of a factory in the state of Bahia will consolidate the process of internationalization of the brand JAC Motors in Brazil.

\section{THE INSTITUTE SHC, A GROUP THE COMPANY IN BRAZIL}

JAC Motors in Brazil invests in social responsibility by means of the SHC Group which is the company that brought JAC to Brazil, so the social initiative described below are not part of the business strategy of the company at an international level, but only for the group in Brazil.

The SHC Institute which was idealized and established in 2008 by entrepreneur Sérgio Habib has a long history of support to communities in the south of the state of Bahia. Located in Trancoso, the Institute is involved with a series of social projects.

The Institute works the education of the population in Trancoso in the state of Bahia. In total, 1,8 thousand children and teenagers are full time assisted in four school units. Besides that, there is a project to nourish kids which helps in complementing the food served at the schools; the project for improvement that contributes with infrastructure works and improvements at the schools, police posts, medical posts etc; the project clean beaches that helps in the maintenance of trash bins that are ecological friendly at the beaches besides helping with garbage collecting. In addition to the educational centers kept by the institute in partnership with local city halls where children have several activities such as, science lab, art room, room with projector, libraries, theater, dance studio, gymnasium, courts for sports, musical starter, choir, string orchestra, support for rural area schools, medical and dental service for the population. The main mission is to form and educate new citizens in Trancoso teaching citizenship and respect to others.

\section{PERCEPTION OF JAC MOTORS IN THE INTERVIEW}

Some perceptions were highlighted in the dialog between the representative of JAC Motors in Brazil and an employee from SHC group.

The people interviewed inform that the executives from JAC and the SHC group understand that the Brazilian consumer likes innovation however they are very conservative yet regarding some preferences in terms of car and accessories. They stated that "a Chinese company has always been perceived as bad quality by Brazilians so how would this be in terms of cars"?

An important internal procedure from Chinese brand JAC Motors to get the new Brazilian 
market is the company's strong concerning with design, technology and quality as well as "the value of service and reception of the customer", according to the people interviewed. So it is necessary to create organizational conditions to meet this requirement.

What drove JAC to get into the Brazilian market besides the potential of a developing country, it was the character and leadership of Sergio Habib to lead the SHC group and successfully bring the brand Citrõen into the Brazilian. The SHC group chose JAC due to the leadership in the manufacturing of light vehicles and the first exportations to China. In addition to JAC being present in over a hundred countries and having a research and development center. The people interviewed also stated that the employees felt proud of working for the company.

Another point in the interview was regarding the aspects related to the organizational behavior in the SHC group, after all those are the ones responsible for the management of the company JAC in Brazil. The people interviewed stated that the company invests a lot in incentive campaigns with awards focusing on driving associates to reach their targets. There is a strong sales strategy focusing on profits; yearly $25 \%$ of employees are replaced in case they do not meet the minimum profile set for efficiency.

The hiring of personnel was then made by the president who personally selected according to his own profile that was bold and able to have fantastic sales, so it is possible to believe that he used his emotional intelligence to select them. Later when the volume of activities increased, this task was delegated to employees. We noticed that what matters is the capacity of learning that the applicants have, therefore, prior experience has a proper but not fundamental value. The rationale converges to the high investments in training and workshops that the company offers their employees so "they commit more", states the those interviewed. Sergio has his desk strategically located at a place in the company close to the employees focusing on the dialog between them.

The company does not have a stated mission, vision and values that according to the people interview it is part of the strategy of the company. There is not SHC group own site, but a JAC Motors site; this is also for strategic reasons.

The people interviewed said that the company has social-environmental practices through the SHC Institute, however there are plans for sustainable management on all their processes.

Regarding the structure, we can highlight the value of its own processes not accepting outsources. They believe that when the process is owned there is more cultural loyalty.

\section{FINAL CONSIDERATION}

After analysis over the concept of internationalization applied to the Chinese automaker JAC Motors in Brazil as well as the understanding of the organizational behavior at the SHC group which brought and has controlled the operations in Brazil since 2010, we can infer the following considerations.

Among the theories of internationalization, it seems to us that the theory conceived by Uppsala University is the one that best reflects the process performed by JAC Motors keeping in sight for the Chinese company: i) the process may take place gradually and slowly focusing on knowledge and experience with the local environment; ii) the process may increase the trust for investment in resources in the country and slowly achieve the process of internationalization as learning over local evolves providing decisions to be made in the country with strategic 
foundation; iii) choice of starting their activities via exportation as well as the cession of the brand and technology transference and this process is made by JAC in Brazil.

What is highlighted in this process of internationalization is the significant financial allocation provisioned by the SHC group. Approximately $90 \%$ of the capital invested is from the Brazilian group that is the major manager of the operations in Brazil. This process may be analyzed in two distinct stages: first, with investment of approximately three hundred million Brazilian reals that were designed to the business stage and the settling of the brand in the Brazilian market, and the second forecasts the implementation of the automaker in the city of Camaçari, in the state of Bahia, and the investment is forecasted to be nine hundred million of Brazilian reals and that will in fact consolidate the process of internationalization of the brand in Brazil.

This process of JAC Motors in Brazil addresses the strategic ambitions both from the Brazilian side and from the Chinese side. On one hand, the SHC group broadens the range of products and expertise in the automotive industry, what provides more consolidation for the Brazilian group which is now more competitive in a highly competitive segment. On the other hand, the Chinese group meets the expectations for the governmental program "GoingGlobal", which proposes to increase Chinese investments abroad. We should highlight that we have here a process that is difficult to manage as it is a product from China and it faces a certain rejection in the Brazilian market. Besides that, we highlight issues with contingent which are beyond the decision capability of SHC group executives, such as US dollar exchange rate, increase of taxes over industrialized goods.

From the point of view of sustainable organizational behavior we have observed a strong company's concerning of encouraging employees to achieve the manufacturing targets, a favorable environment to work, close and charismatic presence of the leader Sérgio Habib, open dialog and solid appearance in the market. And also the allocation of resources for social practices through the SHC Institute located in Trancoso in the state of Bahia. However, it is not evident in the research that a sustainable management is crossing all processes and business strategy of the company as exemplified below.

The company does not expose and therefore does not share in a visible manner their mission, vision and values. This is necessary for the process of the company's transparency before their target public. According to the authors mentioned in this study, this sharing is reflected in the strong organizational identity allowing the employees to have access over the positioning and future of the company they are part of. The management seems to us a little centralized on the leader what makes difficult the decision making and succession plan in the company. We also had the impression that by 2015 vehicle $\mathrm{J} 5$ will be launched in the world market as a hybrid, that is, a car that can be either electric or fuel driven.

Therefore we recommend the company to act strongly on sustainable processes for the manufacturing of automobiles as demonstrated in this article by GM do Brasil that has a technological center built in accordance with the concept of "Green Building", that focus to reduce the utilization of electric energy and natural resources in areas like stamping and painting. One of the main environmental principles adopted by GM is to reduce the generation of residues where all business units have composting practices, water recycling and reuse. Another initiative present in the painting of cars is the utilization of paints with higher solid content in order to 
increase yield and less solvent which results into less emission of organic compounds. GM also values the suppliers as business partners and hires them in accordance with their commitment with corporate responsibility. Upon these and other actions, the company diminished their costs resulting into more gains for the organization. However, one of the measures of sustainable management is the maintenance of jobs, and GM was called in by the Secretary of Treasury of the Ministry of Finance to provide explanations over their lay off plan at their plant in the city of São José dos Campos. The Brazilian federal government has a policy for tax reduction over industrialized products (called IPI in Brazil) for vehicles but on the other hand the government charges the companies the maintenance of jobs in the industry. "We give incentives both financial and taxes, and we want return on that" highlighted President of Brazil, Dilma Rousseff.

With these perceptions we can conclude that it is legitimate and significant for the country the entrance of foreign automakers, in the Brazilian territory, as for instance JAC Motors, main object of our study. Bringing to Brazil their projects for technological innovation focusing on the manufacturing of vehicles that are environmentally sustainable and at the same time on the integration of SHC group in the management of personnel that is compatible with the premises of sustainability, these are the major challenges to be faced and if addressed will be of higher significance for Brazil.

\section{BIBLIOGRAPHIC REFERENCES}

ACIOLY, Luciana; LEÃO, Rodrigo P. F. A China na nova configuração global - impactos políticos e econômicos. Brasília: IPEA, 2011. 352p.

ASHLEY, Patricia Almeida (coord.). Ética e responsabilidade social nos negócios. São Paulo: saraiva, 2003.

ABNT. ASSOCIAÇÃO BRASILEIRA DE NORMAS TÉCNICAS. Informação e documentação. Citações em documentos - Apresentações. NBR-10520. Rio de Janeiro, 2002. 7 p.

BARRET, Richard. Criando uma Organização dirigida por valores. São Paulo: ProLíbera Editora, 2009.

BELMIRO, Nascimento J. et.al. Explorando a internacionalização das empresas brasileiras e sua relação com a inovação tecnológica. Rev. Adm. UFSM, Santa Maria, v.1, n.1, pag. 37-56, jan/abr. 2008.

BELMIRO, Nascimento J. et.al. O processo de internacionalização de uma empresa do setor encarroçador. RAD Vol.14, n.1, p.56-78, Jan/Fev/Mar/Abr 2012.

BILKEY, W. J. Na Atempted Integration of Literature on the Export Behavior of Firms. Journal of international Business Studies, n. 9, p. 33-46, 1978. 
BRUNDTLAND, Gro Harlem. Our common future: the World Commission on Environment and Development. Oxford: Oxford University Press, 1987.

CARAVANTES, G. M., et al. Comportamento Organizacional e Comunicação. Porto Alegre. ICDEP, 2009.

CARLSON, S. Executive Behaviour Uppsala, Sweden: Textguppen I Uppsala AB, 1951.

CAVUSGIL, S. Tamer et al. Negócios Internacionais: estratégia, gestão e novas realidades. São Paulo: Editora Pearson. 2011.

CEBDS. CONSELHO EMPRESARIAL BRASILEIRO PARA O DESENVOLVIMENTO SUSTENTÁVEL. Guia de Comunicação e Sustentabilidade, 2008. Disponível em: <http://www.cebds.org.br >. Acesso em: 10 jul. 2012

CEBC. CONSELHO EMPRESARIAL BRASIL-CHINA. Investimentos Chineses no Brasil: uma nova fase da relação Brasil-China. Disponível em: < http://www.cebc.org.br/pt-br/projetos-e-pesquisas/ investimentos-chineses-no-brasil/investimentos-chineses-no-brasil >. Acesso em: 18 jul. 2012.

DUNNING, J. Towards an eclectic theory of international production: Some empirical tests. Journal of International Business Studies, p. 9-31, Spring/Summer 1980.

DUNNING, J. The eclectic (OLI) paradigm of international production: Past, present and future. Int. J. of the Economics of Business, v. 8, n. 2, p. $173-190,2001$.

DNV, Managing Risks. Triple Bottom Line Reporting. Disponível em: <http://tinyurl.com/6f4jlkj>. Acesso em 18 jan. 2012.

ELKINGTON, John, Chrysalis, Triple Bottom Line, 1994.

ETHOS. Instituto Ethos de Empresas e Responsabilidade Social. Responsabilidade Social Empresarial para Micro e Pequenas Empresas. Disponível em: http://www.ethos.com.br. Acesso em: 05 jun. 2012.

FRANCO, Camila. O futuro é o presente. Revista da General Motors do Brasil, São Paulo, v.49, n.8, p. 08-36, 2010.

GUGLER, Philippe; FETSCHERIN, Marc. The role and importance of the chinese government for chinese outward foreign direct investments. Academy of International Business AIB. Revista Insight. East Lansing, v.10, n. 4, p.12-15, 2010.

HOBBINS, S.P. Comportamento Organizacional. Teoria e prática no contexto brasileiro. 14ㅇ ed. 
São Paulo, Pearson Prentice Hall, 2010.

HOLLAND, Márcio; BARBI, Fernando. China na América latina: uma análise da perspectiva dos investimentos diretos estrangeiros. São Paulo, 2010. 30 f. Texto para Discussão 247. Escola de Economia de São Paulo da Fundação Getúlio Vargas, São Paulo, 2010.

IPEA. INSTITUTO DE PESQUISA ECONOMICA APLICADA. As Relações Bilaterais Brasil - China a Ascensão da China no Sistema Mundial e os Desafios para o Brasil. Brasília: IPEA, 2011 18p.Disponívelem<http://ipea.gov.br/portal/images/stories/PDFs/comunicado/110408_ comunicadoipea 85.pdf . Acesso em 19 jul.2012

IPEA. INSTITUTO DE PESQUISA ECONOMICA APLICADA. A China na nova configuração global impactos políticos e econômicos. Brasília: IPEA, 2011. 352p.

IPEA. INSTITUTO DE PESQUISA ECONOMICA APLICADA. Internacionalização das Empresas Chinesas: As Prioridades do Investimento Direto Chinês no Mundo. Brasília: IPEA,2011,28p. Disponívelhttp://desafios2.ipea.gov.br/portal/images/stories/PDFs/comunicado/110405_ comunicadoipea84.pdf Acesso em 19 jul.2012

ISO. INTERNATIONAL ORGANIZATION FOR STANDARDIZATION. ISO.14000. .Disponível em $<$ http://www.iso.org/iso/home.html >. Acesso em 25 jul.2012.

JOHANSON, J.; VAHLNE. J E. The International Process of the Firm: A Model Knowledge Development and Increasing Foreign Markets Commitments. Journal of International Business Studies., p. 23-32 Spring/Summer, 1977.

JOHANSON, J.; VAHLNE. J. E. The Mechanism of Internationalization. International Marketing Review, v.7, n.4, p.11-24, 1990.

JOHANSON, J.; WIEDERSHEIM. P. The internationalization of the firm: four Swedish cases. Journal of Management Studies, v.12, n.3, p. 305-322, October 1975.

JOHANSON, J.; MATTSSON. L. G .The mechanism of internationalization. International Marketing Review, v. 7, n. 4, p. 11-24, 1990.

KISSINGER, Henry. Sobre a China. Rio de Janeiro: Editora Objetiva, 556 p. 2011.

KUAZAQUI Edmir. A sustentabilidade como estratégia de empresas brasileiras exportadoras. Revista da ESPM, São Paulo, v.17, n.1,caderno especial, 2010.

McGREGOR, James. China's drive for 'Indigenous Innovation: a web of industrial policies. U.S.Chamber of Commerce, 2009. Disponível em < http://www.uschamber.com/reports/chinasdrive-indigenous-innovation-web-industrial-policies >. Acesso em 18 jul.2012. 
PORTER, M. E. Estratégia competitiva: técnicas para análise de indústrias e da concorrência. 7. ed. Rio de Janeiro: Campus, 1986.

SACHS, I. Desenvolvimento includente, sustentável, sustentado. Rio de Janeiro: Editora Garamond, 2004.

SALVATORE, Dominick. Economia Internacional. Rio de Janeiro: Editora LTC, 1999.

SENGE, Peter. A revolução decisiva: como indivíduos e organizações trabalham em parceria para criar um mundo sustentável. Rio de Janeiro: Elsevier, 2009.

SENGE, Peter. Presença: Propósito Humano e o Campo do Futuro. São Paulo, 2007.

SEN, Amartya. A idéia de justiça. São Paulo: Companhia das Letras, 2011. 492p.

TANURE, Betania. Gestão internacional. São Paulo: Editora Saraiva, 2006.

YIP, G. S. Global strategy in a world of nations? Havard Business Review, p.29-41, 1989.

YIP, G. S. Globalização: como enfrentar os desafios da competitividade mundial. São Paulo: Senac, 1996.

YIN, R. K. Estudo de caso: planejamento e métodos. 2. ed. Porto Alegre: Bookman, 2005

WINCHESTER, Simon. O homem que amava a China. São Paulo, Companhia da Letras, 2008. 